\title{
An evaluation of tall fescue, phalaris and cocksfoot in mixes as an alternative to single-species pastures
}

\author{
R.J. JOHNSON*, N.A. THOMSON², D.A. McCALLUM ${ }^{1}$ and T.G. JUDD' \\ ${ }^{1}$ Dairying Research Corporation, Taranaki Agricultural Research Station, PO Box 711, Hawera \\ ${ }^{2}$ Dairying Research Corporation, Privaie Bag 3123, Hamilton
}

\section{Abstract}

Seasonal and annual dry matter production of ryegrass was compared with drought- and grass grub-tolerant species Grasslands Roa tall fescue (Festuca arundinacea Schreb.), Grasslands Maru phalaris (Phalaris aquatica L.) and Grasslands Kara cocksfoot (Dactylis glomerata L.) as both single species and different combinations of mixes in two trials from 1982 to 1991. In trial 1, Nui ryegrass (damaged by Argentine stem weevil) produced significantly less than cocksfoot, phalaris and mixtures of the drought-tolerant grasses. Yatsyn-1 ryegrass in trial 2 was not subjected to stem weevil attack and the annual dry matter production was significantly higher than that of tall fescue and, although not significantly, higher than that of phalaris and cocksfoot. In both trials the highest producing mixture was the phalaris/ cocksfoot mix with the exception of the triple mix of phalaris/cocksfoot/tall fescue in trial 2. The phalaris/cocksfoot mix produced significantly more than phalaris as a single species and although not 14\%significant,-cocksfoot-suggesting

these species are complementary in a mix. The triple mix in trial 2 produced significantly more than all single species except ryegrass. Mixes of tall fescue/phalaris and tall fescue/cocksfoot had no advantage in DM production over single-species sowings of phalaris or cocksfoot, but improved yields over tall fescue. These results show possible complementary effects to sowing phalaris and cocksfoot. The addition of tall fescue to the mix had small and non-significant benefits.

Keywords: Dactylis glomerata, Festuca arundinacea, Lolium perenne, Phalaris aquatica, grass grub, pasture mixes, pasture production, single species, summer dry spells

\section{Introduction}

Grasslands Roa tall fescue (Festuca arundinacea Schreb.), Grasslands Maru phalaris (Phalaris aquatica L.) and Grasslands Kara cocksfoot (Dactylis glomerata L.) were identified by Kain \& Atkinson (1977) and
Judd et al. (1989) as having tolerance to both grass grub (Costelytra zealandica White) and summer dry spells. Grasslands Kara cocksfoot was bred specifically as a grass for dairy pastures (Rumball 1982). It has therefore been recommended that these species be sown as either single or as mixed grass species swards (Charlton 1992; Moloney 1992) in dairying areas prone to summer dry periods and grass grub damage. Lucerne and conventional insecticides have proven ineffective in combating persistent grass grub and summer dry problems in South Taranaki (Thomson et al. 1985), so use of alternative pasture species may be beneficial.

Trials conducted at the Taranaki Agricultural Research Station (TARS) (Thomson \& Barnes 1990), have shown annual dry matter (DM) production of phalaris and tall fescue, established by sowing into cultivated ground, to be $17 \%$ and $20 \%$ more, respectively, than that of old established ryegrass. The annual production of cocksfoot was similar to that of old established ryegrass/clover pasture, but produced more in summer $(9 \%)$ and autumn $(19 \%)$ and less $(15 \%)$ in winter and spring (Judd et al. 1989). These trials compared the growth of single-grass_species swards established in combination with Pitau white clover. From a comparison of the seasonal growth patterns of these species (Judd et al. 1989) it could be postulated that increased benefits in terms of annual DM production and a more even seasonal distribution of growth could possibly be achieved if these grasses were sown as mixtures. Little work has been done on the complementarity of sowing different grass species in mixtures, but McFarlane (1990) and Moloney \& Charlton (1991) suggest that there are possible positive effects.

To investigate the concept of possible benefits from pasture mixes compared with single-grass-species swards, tall fescue, phalaris and cocksfoot were sown as single species and in different combinations of mixes in two trials at TARS and assessed over a period from 1982 to 1991.

\section{M ethod}

\section{Trial 1}

A randomised block design with 4 replicates compared production and persistency of various grasses and grass 
mixtures. Treatments were Nui ryegrass at $18 \mathrm{~kg} / \mathrm{ha}$, Roa tall fescue at $22 \mathrm{~kg} / \mathrm{ha}$, Maru phalaris at $15 \mathrm{~kg} / \mathrm{ha}$, Kara cocksfoot at $10 \mathrm{~kg} / \mathrm{ha}$ and the mixtures tall fescue $x$ phalaris, and cocksfoot $x$ phalaris sown as a 50:50 mix at half the seeding rate sown as' single species. All grasses were sown with $3 \mathrm{~kg} / \mathrm{ha}$ of Pitau white clover. Treatments were established by broadcasting seed into cultivated ground followed by harrowing and rolling.

Pasture production measurements using a rotary mower were taken before each grazing throughout the year in 1982 and 1983 but only during summer and autumn in 1984 and 1985. The composition of sown grass species, white clover and others (other grasses, weeds, dead matter) were measured at each cut. After each assessment the trial area was grazed with dairy cows then trimmed to grazing height with clippings returned. The grazing intervals and grazing intensity were similar to those recommended for high dairy production: 28-day intervals to a pasture height of $6 \mathrm{~cm}$ through spring, summer and autumn and one winter grazing to a height of $2-3 \mathrm{~cm}$.

\section{Trial 2}

A 6-year study from 1985-1991 compared seasonal and annual DM production of Yatsyn-1 perennial ryegrass sown at $15 \mathrm{~kg} / \mathrm{ha}$ with Roa tall fescue at $25 \mathrm{~kg} / \mathrm{ha}$, Maru phalaris at $12 \mathrm{~kg} / \mathrm{ha}$ and Kara cocksfoot at $8 \mathrm{~kg} / \mathrm{ha}$ as pure swards and as two and three grass species mixes (Table 1). To minimise inter-species competition, all mixtures, except the Mix Drilled treatment, were established by drilling each species in single rows through a Duncan 730 triple disk drill with individual seed boxes for each coulter. The trial was established by spraying and drilling, with the exception of the broadcast treatment which was sown into ground prepared by rotary hoeing, harrowing and rolling. All treatments were sown with $2.5 \mathrm{~kg} / \mathrm{ha}$ Pitau white clover. In the fourth year the trial area was closed off from grazing from October 1988 to March 1989 to allow natural reseeding to occur (deferred grazing; McCallum 1991) and from September 1989 a further year's production measurements were taken. Trial measurements and management for trial 2 were similar to those adopted over the first two years of trial 1 with the exception of herbage dissections, which were taken seasonally.

\section{Results}

\section{Trial 1}

\section{Dry matter production}

DM production of ryegrass pastures declined over the trial period (Table 2). Argentine stem weevil damage was evident on Nui ryegrass over the first and second
Table 1 Sowing mixtures and rates in trial $2(\mathrm{~kg} / \mathrm{ha})$.

\begin{tabular}{lccc}
\hline & \multicolumn{3}{c}{ Grass Species } \\
\cline { 2 - 4 } & Tall Fescue & Phalaris & Cocksfoot \\
\hline $\begin{array}{l}\text { Tall Fescue } \\
\text { Phalaris }\end{array}$ & 25.0 & & \\
Cocksfoot & & 12.0 & \\
Tall Fescue/Phalaris & 12.5 & 6.0 & 8.0 \\
Phalaris/Cocksfoot & & 6.0 & 4.0 \\
Tall fescue/Cocksfoot & 12.5 & & 4.0 \\
Tall fescue/Cocksfool & 16.6 & & 2.7 \\
Tall fescue/Cocksfoot & 6.3 & & 5.3 \\
Triple mix & 0.3 & 4.0 & 2.7 \\
Unequal triple mix & 6.3 & 6.0 & 2.0 \\
Mix drilled & 6.3 & 4.0 & 2.7 \\
Mix broadcast & 8.3 & 4.0 & 2.7 \\
\hline
\end{tabular}

Table 2 Dry Matter Production of sown grass species, trial 1 ( DM/ha).

\begin{tabular}{|c|c|c|c|c|}
\hline & \multicolumn{4}{|c|}{ 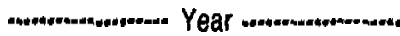 } \\
\hline & 1 & 2 & 3' & 4 ' \\
\hline $\begin{array}{l}\text { Ryegrass } \\
\text { Tall fescue } \\
\text { Cocksfoot } \\
\text { Phalaris }\end{array}$ & $\begin{array}{l}5.0 \mathrm{~b} \\
2.2 \mathrm{c} \\
4.0 \mathrm{~b} \\
7.2 \mathrm{a}\end{array}$ & $\begin{array}{l}4.2 \mathrm{~b} \\
2.9 \mathrm{~b} \\
6.4 \mathrm{a} \\
6.4 \mathrm{a}\end{array}$ & $\begin{array}{l}2.1 \mathrm{~d} \\
1.8 \mathrm{~d} \\
2.6 \mathrm{c} \\
2.6 \mathrm{c}\end{array}$ & $\begin{array}{l}1.5 \mathrm{c} \\
1.9 \mathrm{c} \\
3.1 \mathrm{~b} \\
3.1 \mathrm{~b}\end{array}$ \\
\hline Tall fescue/phalaris & $7.3 \mathrm{a}$ & $7.2 \mathrm{a}$ & $3.1 \mathrm{~b}$ & $3.3 \mathrm{~b}$ \\
\hline $\begin{array}{l}\text { Phalaris/cocksfoot } \\
\text { Significance }\end{array}$ & $7.5 \mathrm{a}$ & $\underset{*}{7.5} \mathrm{a}$ & $4.0 \mathrm{a}$ & $\underset{* *}{4.2 \mathrm{a}}$ \\
\hline LSD 0.05 & 1.4 & 1.4 & 0.3 & 0.4 \\
\hline LSD 0.01 & 1.9 & 1.8 & 0.9 & 1.0 \\
\hline
\end{tabular}

- Sown grass species dry matter production for summer and autumn only

year. DM production of phalaris pastures also declined, but increased for cocksfoot pastures. DM production of tall fescue pastures also increased over the trial period but in all years was significantly less than that of phalaris and cocksfoot pastures.

DM production in years 1, 2 and 4 from the tall fescuefphalaris mix was significantly greater than that of tall fescue but similar to that of phalaris. In summer and autumn of year 3, DM production from tall fescue/ phalaris was significantly greater than that of either tall fescue or phalaris sown as a single species.

In year 1 the phalaris/cocksfoot mix produced significantly more than cocksfoot but was similar to phalaris sown as a single species. In year 2, there was a $15 \%$ increase in DM yield of the phalaris/cocksfoot mix compared with either grass as a single species. By years 3 and 4 this difference in DM production $(+44 \%)$ between mixes and single species for phalaris and cocksfoot was significant.

In all years, the mixes of tall fescue/phalaris and phalaris/cocksfoot produced significantly more than ryegrass. 


\section{Botanical composition}

Over the trial period the content of ryegrass and phalaris declined, tall fescue increased and cocksfoot remained constant (Figure 1). At the beginning of the trial the tall fescue/phalaris mix consisted of 5\% tall fescue and 69\% phalaris; however, by the end of the trial, tall fescue had increased to $15 \%$ and phalaris declined to 48\%. The phalaris/cocksfoot mix initially consisted of $58 \%$ phalaris and $11 \%$ cocksfoot. After 4 years the phalaris had declined to $48 \%$ and the cocksfoot increased to $22 \%$.

\section{Trial 2}

\section{Dry matter production}

For years 1, 2 and 3 (Table 3 ) ryegrass produced significantly more than tall fescue and similar to phalaris and cocksfoot. For combinations of two grasses in a mix, the highest producing treatment was the phalaris/ cocksfoot mix which produced significantly more DM than phalaris and, although not significant, more than cocksfoot sown as a single species. The tall fescue/ cocksfoot mix produced significantly more DM than tall fescue but no more than cocksfoot.

DM production from the triple mix of tall fescue, phalaris and cocksfoot was the highest of the four triple mixtures, producing significantly more than tall fescue, phalaris or cocksfoot sown as single species. Drilling

Figure 1 Botanical composition, autumn, trial 1.

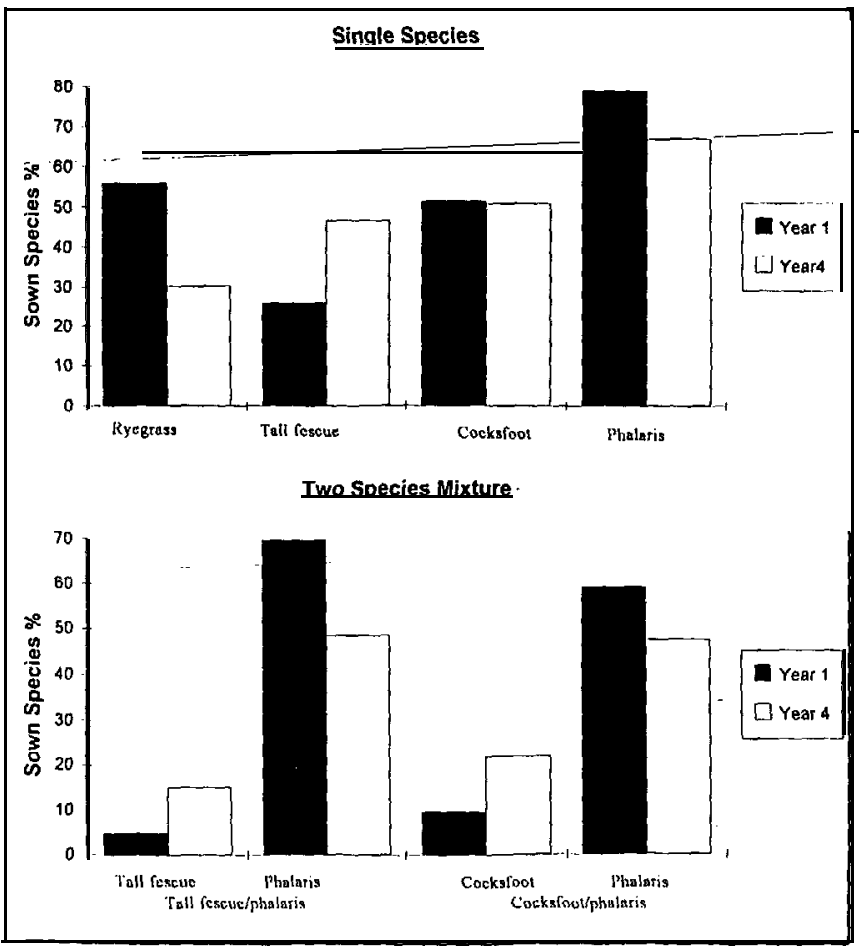

Table 3 Average DM production of sown grass species, trial 2 (tDM/ha).

\begin{tabular}{lcc}
\hline Sowing Mixture & $\begin{array}{c}\text { T DM/ha } \\
\text { Year 1,2 \& } 3\end{array}$ & Following deferral \\
\hline Ryegrass & $4.2 \mathrm{ab}$ & $5.0 \mathrm{a}$ \\
Tall fescue & $2.0 \mathrm{c}$ & $1.3 \mathrm{~d}$ \\
Cocksfoot & $3.9 \mathrm{ab}$ & $3.1 \mathrm{c}$ \\
Phalaris & $3.7 \mathrm{~b}$ & $2.0 \mathrm{~d}$ \\
Phalaris/tall fescue & $3.3 \mathrm{c}$ & $2.2 \mathrm{~d}$ \\
Phalaris/cocksfoot & $4.5 \mathrm{a}$ & $3.5 \mathrm{bc}$ \\
Tall fescue/cocksfoot & $4.0 \mathrm{ab}$ & $2.8 \mathrm{c}$ \\
5 Tall fescuell 1 Cocksfoot & $4.0 \mathrm{ab}$ & $3.1 \mathrm{c}$ \\
11 Tall fescue/5 Cocksfoot & $3.9 \mathrm{ab}$ & $3.0 \mathrm{c}$ \\
Triple mix & $4.7 \mathrm{a}$ & $3.5 \mathrm{bc}$ \\
Unequal triple mix & $4.1 \mathrm{ab}$ & $3.2 \mathrm{c}$ \\
Mix drilled & $4.0 \mathrm{ab}$ & $4.2 \mathrm{~b}$ \\
Mix broadcast & $3.6 \mathrm{bc}$ & $3.4 \mathrm{~b}$ \\
Significance & & $\#$ \\
LSD 0.05 & 0.7 & 0.8 \\
LSD 0.01 & 1.3 & 1.2 \\
\hline
\end{tabular}

species individually in separate rows as a triple mix gave significantly greater DM production than broadcasting mixed seed.

Following deferred grazing and natural reseeding, DM production from ryegrass was significantly greater than from all other treatments. The highest producing mixtures were the phalaris/cocksfoot and most of the triple mixes, producing significantly more DM than phalaris and tall fescue as single species and, although not significant, $11 \%$ more than cocksfoot. All two species mixes including tall fescue were similar and there was no advantage in DM production to including-tall-fescue-in-mixtures-with either cocksfoot or phalaris.

\section{Botanical composition}

The content of ryegrass. phalaris and cocksfoot declined and tall fescue remained constant from year 1 to year 3 (Figure 2). In the phalaris/cocksfoot mix the content of phalaris and cocksfoot declined by 14 and 10 percentage units respectively. In both the tall fescue/phalaris and tall fescue/ cocksfoot mixes the content of tall fescue increased from year one to year three. In the tall fescue/phalaris mix the phalaris increased from $12 \%$ to $26 \%$ and in the tall fescue/cocksfoot mix the content of tall fescue increased with seeding rate. In the triple mix the persistency of each species was similar to that observed in the single species swards; tall fescue increased whereas the cocksfoot and phalaris declined. 
Figure 2 Botanical composition, autumn, trial 2.

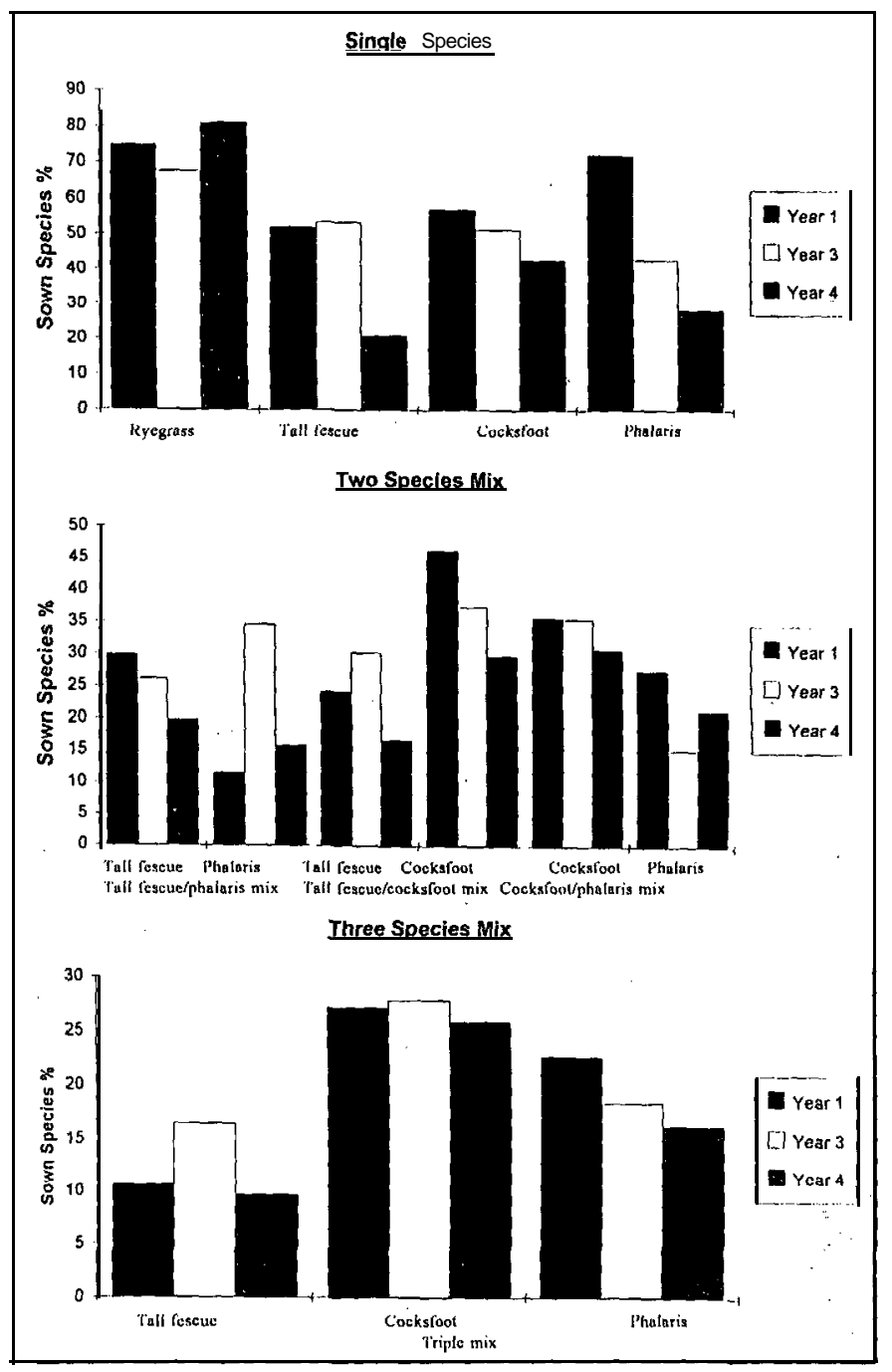

major nutrients and on no occasion did the grasses appear nitrogen deficient. Poor DM production using the cut, trim and graze technique has also been observed in other trials (Hainsworth $e$ al. 1991) and could be attributed to detrimental effect created by multiple defoliation (cutting, grazing and trimming over a short period of $1-2$ days).

In trial 1, the Nui ryegrass was observed to be damaged by Argentine stem weevil and DM production declined markedly (70\%) from autumn 1982 to autumn 1985. In this situation DM production for Kara cocksfoot and Mar-u phalaris sown singly and in mixes was significantly greater than that of ryegrass. Over the first year of the trial, Roa tall fescue produced significantly less than ryegrass and was similar to ryegrass in the remaining years. The ryegrass in trial two, Yatsyn-1, showed no sign of stem weevil damage, indicating higher endophyte levels found to deter Argentine stem weevil attack (Prestidge et al. 1982). For years 1-3 in trial 2 no significant difference between ryegrass and phalaris or cocksfoot, the alternative species sown either as single species or mixed swards with tall fescue, was observed; however, following deferred grazing (allowing natural reseeding) the ryegrass content increased and ryegrass was significantly more productive than any of the alternative species sown singly or in mixes,

The sown-species content of phalaris declined and tall fescue increased in both trials. This result is similar to that of Judd et al. (1989) and Hainsworth et al. (1991) who reported lower persistency of

Following deferred grazing the content of all single species except ryegrass declined. The decline in species content for tall fescue, phalaris and cocksfoot was $60 \%$, $35 \%$ and $20 \%$, respectively. Phalaris, cocksfoot and tall fescue declined in all mixes with the exception of cocksfoot in the tall fescue/cocksfoot mix.

\section{Discussion}

In both trials annual DM production for all sown species was poor $(<6.0 \mathrm{tDM} / \mathrm{ha})$ and less than recorded in grazing trials using the difference technique (Thomson et al. 1988). The reason for the low DM production is not known, as regular soil testing showed no decline in phalaris relative to tall fescue. The content of cocksfoot sown as a single species responded differently in the two trials, remaining constant in trial 1 and declining by $30 \%$ in trial 2 following deferred grazing (allowing natural reseeding). The content of all the alternative species declined, suggesting that these species would not be suitable for deferred grazing. Although the initial establishment of tall fescue was poor, persistency was good. The contribution of tall fescue to the triple mix was small in both trials (10-15\%). Hume \& Lyons (1993), Milne et al. (1993) and Smith et al. (1993) reported that for successful establishment of tall fescue, the summer fallow by either spraying or cultivation is critical. Therefore the method of establishment used 
(spray and drill) in trial 2 may have contributed to the poor yields of tall fescue sown as a single grass species and also the poor contribution of tall fescue when included in a mixture.

In both trials, DM production from the phalaris/ cocksfoot mix was greater than from other treatments with the exception of triple mix of phalaris, cocksfoot and tall fescue in trial two, suggesting that phalaris and cocksfoot are complementary in a mix. The seasonal growth patterns of cocksfoot and phalaris apparently complement each other, the relative advantage of phalaris occurring in autumn and winter and cocksfoot in summer (Judd et al. 1989). The main advantage from the phalaris/cocksfoot mix over the same species as single-species pasture occurred over the summer and autumn period, with winter DM production similar to that of phalaris but greater than that of cocksfoot.

DM production from the tall fescue/phalaris mix in trial 1 was higher than the single-species swards of either tall fescue or phalaris. Botanical composition showed tall fescue contributed less but persisted better than phalaris in the mixture. In trial two, the tall fescue/ phalaris mix had similar DM production to tall fescue and phalaris as single species. The tall fescue/cocksfoot mix was more productive than tall fescue but less productive than cocksfoot sown as a single species pasture. The seasonal growth patterns of tall fescue and cocksfoot are similar (Judd et al. 1989), the relative advantage of both species occurring in summer. From these results a tall fescue/cocksfoot mix or a tall fescue/ phalaris mix would not be recommended.

The triple mix produced significantly-more than the same species sown as single species pastures but not significantly more than the phalaris cocksfoot mix, again highlighting little benefit from using tall fescue in a mixture. These results show benefit in DM production to sowing either a mixture of Kara cocksfoot and Maru phalaris or including Roa tall fescue in the cocksfoot/phalaris mix.

No work has been published on the complementarity of sowing different grass species in mixtures in New Zealand. Moloney (1991) reported that a Roa tall fescue/ Kara cocksfoot pasture mix yielded $18 \%$ more than high endophyte ryegrass. However, Thomson et al. (1988) and Judd et al. (1991) reported a similar yield increase (18\%) from single-grass-species pasture of Roa tall fescue, suggesting that the dryland species rather that the seed mixture is contributing to the increased yield. These trial results are, however, supportive of the concepts presented by MacFarlane (1990) and Moloney \& Charlton (1991) that a grass species mixture is possibly more productive than a pasture containing a single grass species. The additional production obtained from the phalarislcocksfoot mix above either phalaris or cocksfoot sown as a single species demonstrates species complementarity, an aspect that has been hypothesised but not previously demonstrated. Little advantage was achieved by adding tall fescue to either phalaris or cocksfoot or to a mixture of phalaris and cocksfoot, which indicates that tall fescue is incompatible as a companion species with these two grasses.

\section{REFERENCES}

Charlton, J.F.L. 1992. Some basic concepts of pasture seed mixtures for New Zealand farms. Proceedings of New Zealand Grassland Association 53: $37-40$

Hainsworth, R.J; Thomson, N.A; McCallum D.A; Judd T.G. 1991. The evaluation of dryland species and new ryegrass cultivars to increase pasture productivity in South Taranaki. Proceedings of New Zealand Grassland Association 53: 55-58.

Hume, D.E; Lyons, T.B. 1993. Methods of establishing tall fescue and ryegrass in a dryland environment. Proceedings of the New Zealand Grassland Association 53: 105-1 11.

Judd, T.G; Thomson, N.A; McCallum, D.A. 1989 Pasture management and pasture species for improved dry matter production in South Taranaki. Proceedings of the New Zealand Grassland Association 51: 109-112.

Kain, W.M; Atkinson, D.S. 1977. Development of resistant pastures and methods of pasture management of grass grub (Costelytrue Zealandica [White]) control. New Zealand journal of agricultural-research-2.1:-501-51-1-

McFarlane, A.W; 1990 . Field experience with new pasture cultivars in Canterbury. Proceedings of New Zealand Grassland Association 52: 139- 143.

Milne, G.D; Moloney, S.C; Smith, D.R. 1993. Demonstration of dryland species on 90 east coast North Island farms. Proceeding of the New Zealand Grassland Association 55: 39-44.

Moloney, S.C. 1991. Performance of tall fescue, cocksfoot and phalaris based pasture compared with perennial ryegrass, in on-farm trials. Proceedings of the New Zealand Grassland Assōiation 53: 4146.

Prestidge, R.A; Pottinger, R.P; Barker, G.M. 1982. An association of Lolium Endophyte with ryegrass resistance to Argentine Stem Weevil. Proceedings of New Zealand Weed and Pest Control Conference 35: $119-126$.

Rumball, W. 1982. 'Grasslands Kara' cocksfoot (Dactylis glomerata L.) New Zealand journal of experimental agriculture 10:49-50.

Smith, D.R; Slay, M.W.A; Gray, M.H; Milne, G.D. 1993. On farm establishment of drought tolerant 
pasture on the east coast of the North Island.

Proceedings of the New Zealand Grassland Association 55: 33-38.

Thomson, N.A; Barnes, M.L. 1990. Alternative pasture to old ryegrass/white clover for dairying. Dairy Farming Annual 1990: 122-124

Thomson, N.A; Lagan, J.F; McCallum, D.A; Prestidge, R. 1988. An evaluation of 'Grasslands Roa' tall fescue and 'Grasslands Maru' phalaris for dairying. Proceedings of New Zealand Grassland Association 49: 185-191.

Thomson, N.A; Laurence M.R; Popay, A.J; Lagan, J.F; Kain, W.M. 1985. The effect of long term use of insecticide for grass grub control on grass grub numbers and milkfat production. Proceedings of Australasian Conference of Grasslands Invertebrate Ecology 4: 305-3 12 